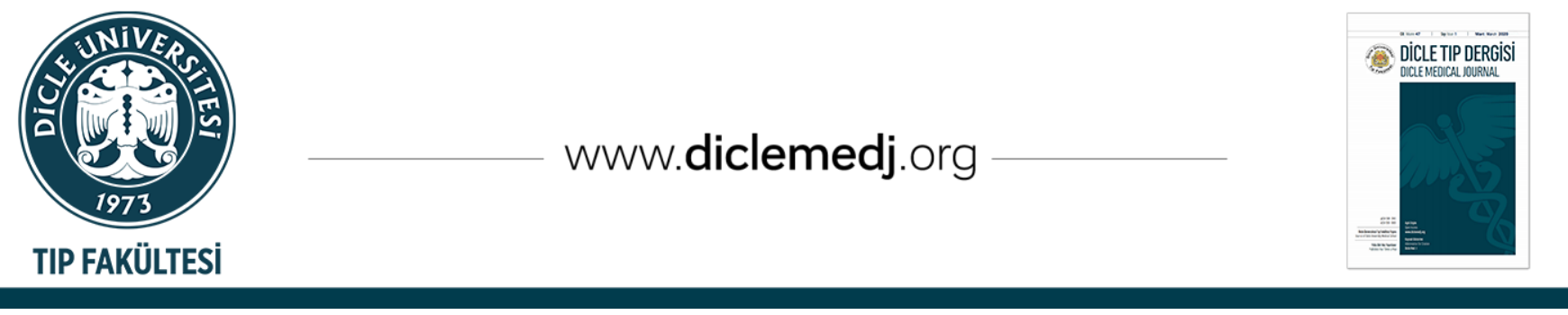

Özgün Araştırma / Original Article

\title{
Erişkin Tip Dikkat Eksikliği ve Hiperaktivite Bozukluğu'nda Kronotip ve Klinik Özellikler
}

\author{
Furkan Coşkun $^{1}$ iD, Lut Tamam² iD, Mehmet Emin Demirkol ${ }^{2}$ iD \\ 1 Elazığ Ruh Sağlığı ve Hastalıkları Hastanesi, Psikiyatri Bölümü Elazığ, Türkiye \\ 2 Çukurova Üniversitesi Tıp Fakültesi Ruh Sağlığı ve Hastalıkları Anabilim Dalı Adana, Türkiye
}

Geliş: 29.01.2020; Revizyon: 17.02.2020; Kabul Tarihi: 17.02.2020

Öz

Amaç: Dikkat Eksikliği Hiperaktivite Bozukluğu (DEHB) çocukluk yıllarında başlayıp, ergenlik ve yetişkinlik döneminde de devam eden bir nörogelişimsel bozukluktur. Biyolojik ve davranışsal yönden bireyler sabahçllık ve akşamcllık șeklinde farklı kronotiplere sahiptirler. Psikiyatrik bozuklukların kronotip farklılıklarıyla ilişkili olduğu düşünülmektedir. Bu çalışmada DEHB'de kronotip ve klinik özelliklerin araştırılması amaçlanmıştır.

Yöntemler: Bu çalışma Çukurova Üniversitesi Tıp Fakültesi'nde yürütmüş ve kesitsel desene sahiptir. Polikliniğe ilk kez başvuran 180 olgu ve psikiyatrik öyküsü olmayan 33 sağlıklı gönüllü çalışmaya dahil edilmiştir. DEHB belirtilerini taramak ve klinik görüşmeye alınacak olguları belirlemek amacıyla Erişkin DEHB Kendi Bildirim Ölçeği ve Erişkin DEHB Tanı ve Değerlendirme Envanteri kullanılmıștır. Klinik görüșmeye alınan olgulara Erișkinlerde DEHB için Tanısal Görüşme, Sabahçılık Akşamcılık Anketi, DSM-IV Eksen I Bozuklukları İçin Yapılandırılmış Klinik Görüşme (SCID-I) uygulanmıştır. Bütün olgularda DSM-5 ölçütleri baz alınarak değerlendirme yapılmıștır.

Bulgular: DEHB'nin psikiyatri polikliniğine ilk kez başvuran olgularda görülme sıklığı \%18.3 bulunmuştur. DEHB tanılı olgularda akşamcılık görülme oranı klinik popülasyona ve kontrol grubuna göre anlamlı oranda yüksek bulunmuştur. Ayrıca DEHB tanılı olgularda erkek cinsiyet ve madde kullanım oranı klinik popülasyona göre anlamlı oranda yüksek bulunmuştur.

Sonuç: DEHB, erişkin psikiyatri polikliniklerinde genel popülasyona göre daha sık görülmektedir. Bu bozukluğa sahip bireylerin biyolojik ve davranışsal ritimlerdeki farklılıklar ve eşlik eden komorbid psikiyatrik tanılar açısından da sorgulanması gerekmektedir. DEHB'nin kronobiyolojik yönü ile ilgili daha fazla sayıda çalışma yapılmasına ihtiyaç duyulmaktadır.

Anahtar kelimeler: erişkin, dikkat eksikliği, hiperaktivite, kronotip

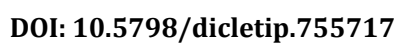

Correspondence / Yazışma Adresi: Mehmet Emin Demirkol, Çukurova Üniversitesi Tıp Fakültesi Ruh Sağlığı ve Hastalıkları Anabilim Dalı, Sarıçam, Adana, Türkiye 01160 e-mail: emindemirkol@gmail.com 


\title{
Chronotype and Clinical Features in Adult Attention Deficit and Hyperactivity Disorder
}

\begin{abstract}
Objective: Attention-Deficit Hyperactivity Disorder (ADHD)is a neurodevelopmental disorder that begins in childhood and continues in adolescence and adulthood. People have different chronotypes in the form of morningness and eveningness from a biological and behavioral point of view. Psychiatric disorders are associated with chronotype differences. In this study, chronotype and clinical features of ADHD were investigated.
\end{abstract}

\begin{abstract}
Method: This cross-sectional study was conducted at Çukurova University School of Medicine. One hundred eighty patients admitted to our outpatient clinic for the first time, and 33 healthy volunteers with no psychiatric history were included in the study. Adult ADHD Self-Report Scale and Adult ADHD Diagnosis and Evaluation Inventory were used to screen for the symptoms of ADHD and to determine the cases to be taken for clinical interview. Diagnostic Interview for ADHD in Adults, Morningness-Eveningness Scale, and Structured Clinical Interview for DSM-IV Axis I Disorders (SCID-I) were applied to the patients who underwent clinical interview. The participants were assessed according to DSM-5 diagnostic criteria.
\end{abstract}

Results: The incidence of ADHD was $18.3 \%$ in patients admitted to psychiatric outpatient clinics for the first time. The incidence of eveningness was significantly higher in patients with ADHD compared to the clinical population and control group. Besides, male sex and substance use rates were significantly higher in patients diagnosed with ADHD compared to the clinical population.

Conclusion: ADHD is more common in adult psychiatric outpatient clinics than in the general population. Individuals with this disorder also need to be questioned in terms of differences in biological and behavioral rhythms and accompanying comorbid psychiatric diagnoses. More studies are needed on the chronobiological aspect of ADHD.

Keywords: Adult, attention deficit, hyperactivity, chronotype

\section{GİRIŞ}

Dikkat Eksikliği Hiperaktivite Bozukluğu (DEHB) çocukluk yıllarında başlayıp, ergenlik ve yetişkinlik döneminde de devam eden bir nörogelişimsel bozukluktur. DEHB azalmış sürdürülebilir dikkat, artmış dürtüsellik ve hiperaktivite ile karakterize bir rahatsızlıktır. Çocuklukta DEHB tanısı alanların \%60-85'i ergenlik döneminde bozukluğun ölçütlerini karşılamaya, \%60 kadarı erişkin hayatta semptomları göstermeye devam eder. Erişkinlerde DEHB ile ilgili epidemiyolojik çalışmalar kısıtlı olmakla birlikte, erişkin dönemde görülme sıklığının \%1-6 oranında olduğu tahmin edilmektedir ${ }^{1,2}$.

DEHB'nin uzun bir süre sadece çocukluk çağı rahatsızlı̆̆ı olduğuna inanılması nedeniyle erişkin dönem özelliklerini inceleyen çalışmaların kısıtlılığı, tanı koymada yaşanan güçlükler ve eşlik eden psikiyatrik tanıların fazlalığı, bu bozukluğun erişkin dönemde yeterince tanınmaması ve tedavisiz kalmasıyla sonuçlanmaktadır. DEHB çocukluk döneminde tanınmadığında erişkin dönemde de sıklıkla tanı koyulamamaktadır. Psikiyatri polikliniklerine çeşitli ruhsal yakınmalarla başvuran birçok olguda altta yatan DEHB varlığ 1 tanınmadığında, tedaviye yetersiz yanıt, lüzumsuz ilaç değişiklikleri, çeşitli işlevsellik alanlarında ortaya çıkan sorunlar ve yüksek psikiyatrik komorbidite oranları gözlenmektedir ${ }^{3}$. Bu durum bireyi, hekimi ve toplumu ilgilendiren önemli bir ruh sağllğı sorunu haline dönüşmektedir. Erişkin dönemde belirtilerin devamını sorgulayan çalışmalarda ergenlik döneminde önce hiperaktivite, sonra dürtüsellik belirtilerinde azalma gözlendiği saptanmıştır. Ancak bozukluğun en örtülü belirtisi olarak görülen dikkatsizlik belirtileri yüksek oranda devam etmektedir ${ }^{3,4}$. Erişkinlik dönemi organize olmayl gerektirdiğinden dikkatsizlik sorunlarının yol açtığı işlevsellik kaybı bu dönemde daha fazladır. DEHB tanılı bireyler sıklıkla başladıkları işlerini bitirememekten, önemli eşya ve belgeleri kaybetmekten, posta, önemli evraklar ve 
faturaları düzenleme ve takip etmede güçlükten yakınırlar. Organizasyon ve planlama alanlarındaki güçlükler, vazgeçmeye, kaytarmaya, endișe ve yetersizlik duygularının gelişimine ve iş gücü kaybına yol açar³.5.

Tüm organizmaların biyolojik aktiviteleri belirli bir ritme uygun olarak meydana gelir. Kronobiyoloji ise bu ritimleri moleküler düzeyden klinik görünümlerine kadar pek çok yönden inceleyen bilim dalıdır. İnsanlarda hastalıklı ve sağlıklı dönemlere ait biyolojik ritimlerin gösterilmesi, hastaların tanı ve tedavi süreçleri açısından tıbbi gelişmelere katkıda bulunmuştur6. İnsanlar uyku uyanıklık döngüsü, vücut sıcaklığı, kortizol ve melatonin salgılanma zamanı gibi biyolojik ve davranışsal ritimlerdeki farklılıklar açısından "morningness (sabahçll)" ve "eveningness (akşamcil)" şeklinde farklı kronotiplere sahiptirler. Sabahçıl tipler daha erken yatar ve erken kalkarlar, sabah erken saatlerde daha iyi performans gösterirler. Akşamcl tipler ise geç saatlerde uyurlar ve aktiviteleri açısından akşam saatlerini tercih ederler6,7. Her iki tip arasında vücut sıcaklığı, kortizol ve melatonin gibi hormonların salınım dönemlerinde de belirli yaklaşık 2 saatlik bir faz farkı mevcuttur6,8.

Yapılan çalışmalar sirkadiyen ritimdeki farklılıkların depresyon, uyku bozuklukları, özkıyım girișimi gibi ruhsal ve davranışsal sorunlar ile ilişkili olduğunu ortaya koymaktadır. Kronobiyolojik bozuklukların çeşitli yaş gruplarında DEHB patofizyolojisine ve ortaya çıkardığı işlevsellik kaybına katkıda bulunduğu düşünülmektedir. Yapılan çalışmalarda DEHB olgularında genel popülasyona göre daha fazla oranda akşamcı kronotip saptandığı ve bu durumun dikkat problemleri, hiperaktivite, dürtüsellik, yıkıcı davranışlar, uyku bozuklukları, ailevi, sosyal ve mesleki alanda ortaya çıkan çeşitli sorunlar ile ilişkili olduğu belirtilmektedir ${ }^{6,9,10}$. Söz konusu ilişkinin ortaya çıkarılması için yapılacak çalışmalar, DEHB'nin dikkatsizlik ve/veya hiperaktivite/dürtüsellik belirtileri dışında farklı yönleriyle de ele alınarak bütüncül olarak kavranmasına ve kronobiyolojik temelli tedavilerin geliştirilerek kullanılmasına yardımcı olacaktır.

$\mathrm{Bu}$ çalışmada Çukurova Üniversitesi Tıp Fakültesi Psikiyatri Polikliniği'ne ilk kez başvuran olgularda DEHB görülme sıklı̆̆ının belirlenmesi, $\tan 1$ koyulan olguların sosyodemografik, klinik ve kronotip özelliklerinin araştırılması amaçlanmıştır.

\section{YÖNTEMLER}

Çukurova Üniversitesi Tıp Fakültesi Balcalı Hastanesi Psikiyatri Polikliniği'nde yürütülmüş olan çalışmanın örneklem grubunu polikliniğimize Kasım 2017-Nisan 2018 tarihleri ilk kez bașvuran, araștırmaya katılmaya gönüllü olan, 18-65 yaş aralığında, kendisine verilen ölçekleri doldurabilecek eğitim düzeyine sahip ve dışlama ölçütlerini karşılamayan 180 olgu oluşturmaktadır. Ayrıca çocukluk çağı veya erişkin dönemde DEHB tanısı almamış, aktif bir ruhsal yakınması veya devam eden psikiyatrik tedavisi olmadığ öğrenilen, 18-65 yaş aralığında hastalarla aynı çevrede yaşayan hastane çalışanı ve hasta yakınlarından oluşan 33 kişi kontrol grubu olarak çalışmaya dahil edilmiștir. Çalıșmaya dahil edilme ölçütleri; polikliniğimize ilk kez başvurmak, araştırmaya katılmaya gönüllü olmak, 18-65 yaş arasında olmak, okur/yazar olmak olarak, dışlama ölçütleri; zeka geriliği veya yetersizliği, ağır fiziksel, nörolojik, bilişsel bozukluğa sahip olmak, sağlık kurulu raporu düzenlenecek olmak olarak belirlenmiștir.

\section{Prosedür}

Çalışmanın etik kurul onayı ÇÜTF Girişimsel Olmayan Klinik Araştırmalar Etik Kurulu tarafından verilmiştir $\quad(10.11 .2017$ tarihli toplantı, 11 no'lu karar). Aydınlatılmış Onam Formu'nu doldurarak çalışmaya katılmaya onam veren olgulardan, Sosyodemografik Veri Formu, Erişkin Dikkat Eksikliği Hiperaktivite 
Bozukluğu Kendi Bildirim Ölçeği (ASRS) ile birlikte Turgay'ın DSM-IV'e Dayalı Erişkin DEHB Tanı ve Değerlendirme Envanteri' ni doldurmaları istenmiştir ${ }^{11,12}$. Tarama ölçeklerinin herhangi birinden kesme puanının üzerinde skor alan (ASRS'nin A bölümündeki taralı alanlarda 4 ya da daha fazla maddeyi işaretleyenler; Turgay'ın DSM-IV'e Dayalı Erişkin DEHB Tanı ve Değerlendirme Envanteri'nde 1. veya 2. bölümdeki dokuzar sorudan en az beş tanesine 2 veya 3 puan verenler) olgular klinik görüşmeye alınmıştır. Görüşmeler sırasında olguların 1. veya 2. derece yakınlarından çocukluk çağı hakkında bilgi alınmaya çalışılmıştır. DEHB tanısı koyulan olgulara Sabahçlık Akşamcllık Anketi (SAA), DSM-IV Eksen I Bozuklukları İçin Yapılandırılmış Klinik Görüşme (SCID-I) uygulanmıştır ${ }^{13,14}$.

DEHB'de DSM-IV-TR'den DSM-5'e geçişte A tanı ölçütünde bulunan belirtiler aynı kalmakla birlikte, DSM-IV-TR'de çocukluk çağı ve erişkin dönemde en az altı belirti olması şartı aranmaktayken; DSM 5'te '17 yaşında ve daha büyüklerde en az beș belirti ortaya çlkması' şartı yer almaktadır. Ayrıca B tanı ölçütünde DSM-IV-TR'de 7 yaşından önce belirtilerin birkaçının ortaya çıkmış olması şartı aranmaktayken; DSM-5'te 'birkaç dikkatsizlik ve/veya hiperaktivite / dürtüsellik belirtisinin 12 yaşından önce ortaya çıkması' şartı yer almaktadır ${ }^{15,16}$. Bütün olgularda klinik görüşme ve tanı koyma aşamasında, söz konusu değiş̧ikliklerde dikkate alınarak DSM-5 tanı kriterlerine göre değerlendirme yapılmıştır. DEHB tanısı koyulan olguları kronotip tercihi yönünden normal popülasyon ile karşılaştırmak amacıyla çocukluk çağı veya erişkin dönemde DEHB tanısı almamış, aktif bir ruhsal yakınması veya devam eden psikiyatrik tedavisi olmadığı öğrenilen, 18-65 yaş aralığında bulunan bireylerden kontrol grubu oluşturulmuştur. Kontrol grubunda yer alan olgulara Aydınlatılmış Onam Formu,
Sosyodemografik Veri Formu ve Sabahçılık Akşamcılık Anketi uygulanmıștır.

\section{Sosyodemografik Veri Formu}

Katılımcılar yaș, cinsiyet, medeni durum, eğitim düzeyi, mesleki durum gibi sosyodemografik verileri yanı sıra, sigara, alkol, madde kullanımı, kumar oynama, bedensel veya ruhsal hastalık öyküsü, ilk psikiyatriye başvuru zamanı, ailede ruhsal hastalık öyküsü, geçmişte kendisi veya ailesinde intihar girişimi öyküsü, sık iş değiștirme öyküsü, ev, iş ya da trafik kazası geçirme öyküsü, adli sorun yaşama öyküsü gibi çeşitli konularda sorgulanmıştır.

Erişkin Dikkat Eksikliği Hiperaktivite Bozukluğu Kendi Bildirim Ölçeği (ASRS)

Dünya Sağlık Örgütü (DSÖ) tarafından ruhsal bozuklukların taranması amacina yönelik geliştirilen ölçeklerden biridir ${ }^{11,17}$. Ölçekte yer alan sorular DSM-IV-TR'de DEHB tanisı koyarken kullanılan belirtileri içerir. Ölçek A ve $\mathrm{B}$ bölümünden oluşmaktadır. A bölümünde DEHB belirtilerini daha iyi kestirebildiği gösteren 6 soru, $B$ bölümünde 12 soru bulunmaktadır. Ölçeğin A bölümündeki taralı alanlarda işaretli 4 ya da daha fazla maddenin olması DEHB belirtileri açısından anlamlı bulunmakta ve bu durumda ileri değerlendirme önerilmektedir ${ }^{11}$.Sorular her belirtinin son altı ay içinde hangi sıklıkta ortaya çıtığını belirlemeye yöneliktir. Sorular asla-çok sık yanıtlarına göre 0-4 arasında puanlanmaktadır. Türkçe formunun geçerlilik ve güvenilirlik çalışması yapılmıştır ${ }^{11}$.

Turgay'ın DSM-IV'e Dayalı Erişkin DEHB Tanı ve Değerlendirme Envanteri

DSM-IV tanı kriterlerine göre geliştirilmiş, Türkçe geçerlilik ve güvenilirlik çalışması yapılmıştır ${ }^{12,18}$. Dikkat eksikliği bölümü, hiperaktivite/dürtüsellik bölümü, dikkat eksikliği ve hiperaktivite bozukluğu ile ilişkili klinik deneyim ve gözlemlere göre oluşturulan 3 alt bölümden oluşmaktadır. 
Ölçek değerlendirilirken 0 ve 1 puanlar negatif; 2 ve 3 puanlar ise pozitif kabul edilmiştir. 1 . veya 2 . bölümdeki dokuzar sorudan en az beş tanesine 2 veya 3 puan verenler sirasiyla 'Dikkat Eksikliği' ve 'Hiperaktivite/Dürtüsellik' grubu olarak kabul edilmektedir. Genel toplamda ise 20'nin altında alanların 'düşük düzeyde DEHB', 20 ile 59 arasında puan alanların 'orta derecede DEHB', 59'un üstünde puan alanların ise 'yüksek düzeyde DEHB' belirtileri gösterdiği belirtilmiştir ${ }^{12,18}$.

\section{Sabahçılık-Akşamcılık Anketi (SAA)}

İnsanları yaşam biçimleri, uyku-uyanıklık düzenleri ve gösterdikleri performans bakımından sorgulayan 19 sorudan oluşmaktadır. Öz bildirim türünde değerlendirme ölçeğidir ${ }^{13}$. Toplam puan 16-41 arası 'akşamcıl', 42-58 arası 'ara tip', 59-86 arası 'sabahçıl' olarak sınıflandırılmaktadır. Anketin Türkçe verisyonunun güvenilirlik çalışması 2005 yılında yapılmıştır ${ }^{19}$.

DSM-IV Eksen I Bozuklukları için Yapılandırılmış Klinik Görüşme (SCID-I)

DSM-IV'e göre eksen I bozukluk tanılarının araştırılması amacıyla geliştirilmiş, klinisyen tarafından uygulanan, yarı yapılandırılmış klinik görüşme formudur. Duygudurum bozuklukları, şizofreni ve diğer psikotik bozukluklar, madde kullanımı ile ilişkili bozukluklar, anksiyete bozuklukları, somatoform bozukluklar, yeme bozuklukları ve uyum bozuklukları modüllerinden oluşmaktadır. Tanısal değerlendirme 'şu anda' ve 'yaşam boyu' göz önüne alınarak gerçekleştirilir. Türkçe güvenilirliği ve uyarlaması yapılmıştır ${ }^{20}$.

İstatistiksel Analiz

Araştırmanın verilerinin girilmesi ve istatistiksel analizi IBM SPSS Statistics 24.0 programı ile yapılmıştır. Kategorik değişkenlerin karşılaştırılmasında Ki-kare testi, numerik değişkenlerin karşılaştırılmasında $\mathrm{t}$ testi kullanılmıştır. Çoklu gruplarda ölçüm verilerinin karşılaştırılmasında ANOVA kullanılmıştır. Kategorik değişkenler \% ve sayı şeklinde, numerik değişkenler ise "ortalama \pm standart sapma" şeklinde gösterilmiştir. p değerinin 0.05'ten küçük olması durumunda gruplar arası fark istatistiksel olarak anlamlı kabul edilmiştir.

\section{BULGULAR}

Polikliniğimize ilk kez başvuran 180 olgudan 33'üne $(\% 18,3)$ klinik görüşme sonucunda DEHB tanısı koyulmuştur. DEHB tanısı alan olguların yaş ortalaması $30.42 \pm 11.24$, DEHB tanısı almayanların $30.94 \pm 10.56$ olmakla birlikte gruplar arasında anlamlı farklılık bulunmamaktadir $(\mathrm{p}>0.05)$. DEHB tanıl olguların \%57,6'sı erkek (n=19), \%42,4'ü kadın $(\mathrm{n}=14)$, DEHB tanısı almayanların \%63,9'u kadin (n=94), \%36,1'i (n=53) erkek olup aradaki fark anlamlı bulunmuştur $(\mathrm{p}=0.023)$. Medeni durum, eğitim düzeyi ve mesleki durum arasında gruplar arasında anlamlı farklılık bulunmamaktadır. DEHB tanısı alan ve almayan olgular arasında sigara ve madde kullanımı konusunda anlamlı fark saptanmamıştır ( $p>0.05)$. DEHB tanilı olgularda alkol kullanımının istatistiksel olarak anlamlı şekilde daha yüksek olduğu saptanmıştır $(p=0.009)$ (Tablo 1'e bakınız). Çalışmamızda DEHB tanılı olguların ailelerinde (1. ve 2. derece yakınları) ruhsal hastalık bulunma oranı $(\% 42,4)$, DEHB tanısı almayanlara göre (\%19) istatistiksel olarak anlamlı oranda yüksek bulunmuştur. Ayrıca çalışmamızda DEHB tanılı olgularda sık iş değişikliğinde bulunduğunu bildirenlerin oranı $(\% 36,4)$, DEHB tanısı almayanlara göre $(\% 6,8)$ istatistiksel olarak anlamlı oranda yüksek bulunmuştur. 
Tablo I: DEHB Tanısı Alan ve Almayan Olguların Sosyodemografik Özelliklerine Göre Karşılaştırılması

\begin{tabular}{|c|c|c|c|}
\hline Değişkenler & DEHB $(n=33)$ & $\begin{array}{ll}\text { DEHB } & \text { tanısı } \\
\text { almayan }(n=147)\end{array}$ & $\mathbf{p}$ \\
\hline Yaş (ort $\pm s s$ ) & $30.42 \pm 11.24$ & $30.94 \pm 10.56$ & 0.653 \\
\hline \multicolumn{4}{|l|}{ Cinsiyet } \\
\hline Kadın & $14(\% 42,4)$ & $94(\% 63,9)$ & \multirow{2}{*}{$0.023 *$} \\
\hline Erkek & $19(\% 57,6)$ & $53(\% 36,1)$ & \\
\hline \multicolumn{4}{|l|}{ Medeni Durum } \\
\hline Bekar & $21(\% 63,6)$ & $81(\% 55,1)$ & \multirow{2}{*}{0.371} \\
\hline Evli & $12(\% 36,4)$ & $66(\% 44,9)$ & \\
\hline \multicolumn{4}{|l|}{ Ĕgitim Düzeyi } \\
\hline Eğitimsiz & $0(\% 0)$ & $2(\% 1,4)$ & \multirow{4}{*}{0.262} \\
\hline İlköğretim & $12(\% 36,4)$ & $31(\% 21,1)$ & \\
\hline Lise & $10(\% 30,3)$ & $61(\% 41,5)$ & \\
\hline Önlisans/Lisans & $11(\% 33,3)$ & $53(\% 36,1)$ & \\
\hline \multicolumn{4}{|l|}{ Çalışma } \\
\hline Çalışıyor & $8(\% 24,2)$ & $36(\% 24,5)$ & \multirow{2}{*}{0.976} \\
\hline Çalıșmıyor & $25(\% 75,8)$ & $111(\% 75,5)$ & \\
\hline \multicolumn{4}{|l|}{ Sigara } \\
\hline Var & $15(\% 45,5)$ & $55(\% 37,4)$ & 0.392 \\
\hline \multicolumn{4}{|l|}{ Alkol } \\
\hline Var & $9(\% 27,3)$ & $15(\% 10,2)$ & 0.009* \\
\hline \multicolumn{4}{|l|}{ Madde } \\
\hline Var & $2(\% 6,1)$ & $3(\% 2)$ & 0.204 \\
\hline
\end{tabular}

DEHB tanılı olguların Erişkin DEHB Kendi Bildirim Ölçeği ve DSM-IV'e Dayalı Erişkin DEHB Tanı ve Değerlendirme Envanteri'nin 1. ve 2. bölümlerinden aldığı puanların, DEHB tanısı almayanlara göre anlamlı ölçüde yüksek olduğu saptanmıştır ( $\mathrm{p}<0.001)$ (Tablo 2).
Tablo II: DEHB Tanısı Alan ve Almayan Olguların Tarama Ölçek Puanlarına Göre Karșılaștırılması

\begin{tabular}{|c|c|c|c|}
\hline Değişkenler & DEHB $(n=33)$ & $\begin{array}{l}\text { DEHB tanisı } \\
\text { almayan } \\
(n=147)\end{array}$ & $\mathbf{P}$ \\
\hline ASRS (ort \pm ss) & $47.15 \pm 11.07$ & $29.24 \pm 11.71$ & $<0.001 *$ \\
\hline $\begin{array}{l}\text { Turgay 1. Bölüm } \\
\text { (ort } \pm \text { ss) }\end{array}$ & $19.45 \pm 5.12$ & $9.68 \pm 5.72$ & $<0.001 *$ \\
\hline $\begin{array}{l}\text { Turgay 2. Bölüm } \\
\text { (ort } \pm \text { ss) }\end{array}$ & $14.88 \pm 6.91$ & $8.25 \pm 4.96$ & $<0.001 *$ \\
\hline
\end{tabular}

ASRS: Erişkin Dikkat Eksikliği Hiperaktivite Bozukluğu Kendi Bildirim Ölçeği

Turgay 1. ve 2. Bölüm: Turgay'ın DSM-IV'e Dayalı Erişkin DEHB Tanı ve Değerlendirme Envanteri 1. ve 2. Bölüm

Sabahçılık Akşamcılık Anketi (SAA) ile yapılan değerlendirme DEHB tanılı olguların, \%54.5'i $(n=18)$ ara tip, \%33.3'ü $(n=11)$ akşamcl tip, \%12.1'i (n=6) sabahçı tip olarak saptanmıştır. DEHB tanısı almayan olguların \%59.2'si $(n=87)$ ara tip, \%29.9'u (n=44) sabahçı tip, \%10.9'u $(n=16)$ akşamcı tip olarak saptanmıştır. Kontrol grubunda yer alan (n=33) olguların \%69.7'si $(n=23)$ ara tip, \%27.3'ü $(n=9)$ sabahçı tip, \%3'ü $(n=1)$ akşamcı tip olarak saptanmıştır. DEHB tanılı olgularda akşamcı tip görülme oranı, DEHB tanısı almayanlara $(\mathrm{p}=0.002)$ ve kontrol grubuna $(p=0.004)$ göre anlamlı oranda yüksek saptanmıştır. DEHB tanısı almayan olgular ile kontrol grubu arasında yapılan karşılaştırmada istatistiksel olarak anlaml bir farklılık saptanmamıştır $(\mathrm{p}=0.315)$. (Tablo 3 ve $4^{\prime} \mathrm{e}$ bakınız)

Tablo III: DEHB Tanısı Alan ve Almayan Olguların Kronotip Dağılımına Göre Karşılaștırılması

\begin{tabular}{|l|l|l|l|}
\hline Değişkenler & DEHB (n=33) & $\begin{array}{l}\text { DEHB tanıSı } \\
\text { almayan (n=147) }\end{array}$ & P \\
\hline Sabahçılık & $4(\% 12,1)$ & $44(\% 29,9)$ & \multirow{2}{*}{.002* } \\
\cline { 1 - 3 } Ara tip & $18(\% 54,5)$ & $87(\% 59,2)$ & \\
\hline Akşamcllık & $11(\% 33,3)$ & $16(\% 10,9)$ & \\
\hline
\end{tabular}


Tablo IV: DEHB Tanılı ve Kontrol Grubunda Yer Alan Olguların Kronotip Dağılımına Göre Karşılaştırılması

\begin{tabular}{|l|l|l|l|}
\hline Değişkenler & DEHB (n=33) & Kontrol (n=33) & P \\
\hline Sabahçlık & $4(\% 12,1)$ & $9(\% 27,3)$ & \\
\hline Ara tip & $18(\% 54,5)$ & $23(\% 69,7)$ & \multirow{2}{*}{.04* $^{*}$} \\
\cline { 1 - 3 } Akşamcllı & $11(\% 33,3)$ & $1(\% 3)$ & \\
\hline
\end{tabular}

DSM-5 tanı ölçütleri dikkate alınarak uygulanan SCID-I sonucunda, DEHB tanisı alan $(n=33)$ olguların \%81.8'ine $(n=27)$ eşlik eden ruhsal hastalık tanısı koyulmuştur. Olguların 16'sına (\%48) birden fazla eşlik eden ruhsal hastalık tanısı koyulmuştur. (Tablo 5'e bakınız).

Tablo V: DEHB Tanılı Olguların Komorbid Psikiyatrik Tanı Dağılımı

\begin{tabular}{|l|l|}
\hline TANI & DEHB (n=33) \\
\hline Depresif Bozukluklar & $16(\% 48,4)$ \\
\hline Anksiyete Bozuklukları & $10(\% 30,3)$ \\
\hline Dürtü Kontrol Bozuklukları & $8(\% 24,2)$ \\
\hline Alkol ve Madde Kullanım Bozuklukları & $3(\% 9)$ \\
\hline Obsesif Kompulsif Boz. ve İlişkili Bozukluklar & $2(\% 6)$ \\
\hline Uyku-Uyanıklı Bozuklukları & $2(\% 6)$ \\
\hline Somatoform Bozukluk ve İlişkili Bozukluklar & $1(\% 3)$ \\
\hline Travma ve Stresörle İlişkili Bozukluklar & $1(\% 3)$ \\
\hline
\end{tabular}

\section{TARTIŞMA}

DEHB'nin erişkin dönemde görülme sıklı̆̆ı ile ilgili genel popülasyon üzerinde yapılan geniş örneklemli epidemiyolojik araştırmalarda; dünya çapında yaygınlığın $\% 3,4$, gelişmiş ülkelerde ise $\% 4,2$ oranında olduğu bildirilmektedir ${ }^{3,21}$. Ayaktan psikiyatriye başvuran olgular üzerinde yapılan çalışmalarda, psikotik olmayan erişkin hastalarda DEHB prevalansı $\% 16,8$ ve $\% 17,4$ olarak saptanmıştır ${ }^{22}$. Ülkemizde yapılan çalışmalara bakıldığında, genel psikiyatri polikliniğine başvuran olgularda yaygınlık oranları \%1,6 ve $\%$ olarak bildirilmektedir ${ }^{23,24}$.
Çalışmamızda DEHB'nin görülme sıklığı oranı $\% 18,3$ olarak bulunmuştur. Bu oranın genel popülasyona göre oldukça yüksek olduğu görülmektedir. Ülkemizde yapılan çalışmalarda bildirilen yaygınlık oranlarının birbirine benzer olmaması metodolojik farklılıklardan kaynaklanıyor olabilir.

Ülkemizde ayaktan psikiyatri polikliniğine başvuran olgular üzerinde yapılan ve DEHB türlerini araştıran iki çalışmaya bakıldığında; ilk çalışmada en sık dikkatsizlik alt tipi (\%46), ikinci sıklıkta bileşik tip (\%44), son olarak da hiperaktivite ve dürtüselliğin baskın olduğu tip (\%10) saptandığı bildirilirken, diğer çalışmada en sık bileşik tip (\%55), ikinci siklıkta dikkatsizliğin baskın olduğu tip (\%30), son olarak da hiperaktivite/dürtüselliğin baskın olduğu tip (\%15) saptandığı bildirilmektedir ${ }^{24}$. Erişkinlerde DEHB ile ilgili yapılan bir metaanaliz çalışmasında genel toplum örnekleminde dikkatsizliğin baskın olduğu tipin, klinik örneklemde bileşik tipin daha sık görüldüğü belirtilmiştir ${ }^{25}$. Çalışmamızda DEHB tanısı koyulan olguların alt tiplere göre dağılımı incelendiğinde, en sık dikkatsizliğin baskın olduğu tip $(\% 48,5)$, ikinci sıklıkta bileşik tip $(\% 33,3)$, son olarak da hiperaktivite / dürtüselliğin baskın olduğu tip $(\% 18,2)$ saptanmıştır. Bu sonuç literatürde yer alan bazı çalışmaların sonucuyla uyumlu gözükürken, farklı çalışmalarda klinik örneklemde en sık bileşik tip görüldügü bildirilmektedir. Erişkinlerde hiperaktivite / dürtüselliğin baskın olduğu tipin en az sıklıkta görülmesi sonucu ise literatürde yer alan çalışmalarla uyumlu gözükmektedir.

Epidemiyolojik ve klinik örneklemli çalışmalarda DEHB'nin erkeklerde daha sık görüldüğü bildirilmektedir. Çocuklarda ve ergenlerde erkek/kız oranı erişkinlere göre daha yüksektir ${ }^{26}$. Erişkin dönemle ilgili yapılan çalışmalarda erkek/kadın oranının 1,5-2 olduğu belirtilmektedir. Erişkin dönemde bu farkın yaş ilerledikçe azaldığ ${ }_{1} \quad$ bildirilmektedir ${ }^{27}$. 
Çalıșmamızda cinsiyetler arası dağılım incelendiğinde DEHB tanısı alan olguların \%57,6'sı erkek, \%42,3'ü kadın; DEHB tanısı almayan olguların \%63,9'u kadın, \%36.1'i erkektir. Cinsiyetler arası dağılımdaki fark istatistiksel olarak anlamlı bulunmuştur. Ayrıca DEHB tanısı alanlarda erkek/kadın oranı yaklaşık 1.35 olarak hesaplanmıştır. Çalışmamızda DEHB'nin erkeklerde daha sık saptanması mevcut literatürle uyumlu görülmektedir.

DEHB' li çocukların anne, baba ve kardeşlerinde topluma göre artmış risk olduğu bilinmektedir ${ }^{28}$. Ayrıca DEHB' nin duygudurum bozuklukları ile yüksek birliktelik oranları nedeniyle her iki bozukluğun ortak genetik ve psikososyal faktörlerden kaynaklanabileceği öne sürülmüştür ${ }^{29}$. Ayrıca aile içi süreçlerde yaşanan zorluklar nedeniyle ebeveynlerde anksiyete ve depresyon gibi ruhsal bozukluk tanıları artmıștır ${ }^{30}$. Çalışmamızda DEHB tanılı olguların ailelerinde ruhsal hastalık bulunma oranı, DEHB tanısı almayanlara göre anlamlı oranda daha yüksek bulunmuştur.

DEHB'li erişkinlerde iş başarısızlığ ve işsizliğin normal popülasyondan çok daha yüksek olduğu bilinmektedir ${ }^{31}$. Amerika Birleşik Devletleri' nde yapılan bir çalışmada bireylerin çalıştıkları bir işte devamlılık süresi ortalama 21.5 ay iken, DEHB tanılı bireylerde bu sürenin 9 ay olduğu bildirilmektedir ${ }^{32}$. Çalıșmamızda DEHB tanılı olgularda sık iş değişikliğinde bulunduğunu bildirenlerin oranı, DEHB tanısı almayanlara göre anlamlı oranda yüksek bulunmuştur. Çalışmamızda elde ettiğimiz bu sonuçlara göre DEHB'de sık iş değişikliğinde bulunduğunu bildirenlerin oranının klinik popülasyona göre artmış olduğu görülmektedir. $\mathrm{Bu}$ sonuç literatürde yer alan DEHB'li olgularda işe devamlılık süresinin kısaldığı yönündeki bulguları desteklemektedir.

Kronotip tercihinde genetik, çevresel ve yapısal pek çok faktörün rolü olduğu düşünülmektedir. Bu konuda yapılan çalışmalar erişkin DEHB'de sirkadiyen tercihin akșamcllık yönünde olduğunu göstermektedir 33,34 . DEHB ve kronotip tercihi ilişkisini inceleyen çalışmalarda, akşamcı kronotip ile dikkat problemleri, hiperaktivite, dürtüsellik, yıkıcı davranışlar, uyku bozuklukları arasında ilişki olduğu bildirilmektedir 35 . Almanya'da yapılan bir çalışmada ilaç kullanmayan erişkin DEHB tanılı olgular, epifiz bezi büyüklüğü, kronotip tercihi ve semptom şiddeti açısından sağlık kontrollerle karşslaştırılmıştır. Erişkin DEHB tanılı olguların epifiz bezi hacminin sağlıklı kontrollere göre daha küçük olduğu ve daha fazla oranda akşamcı kronotip sergilediği saptanmıştır. Ayrıca epifiz bezi hacmi ile kronotip tercihi arasında da bir bağlantı olduğu saptanmıştır ${ }^{36}$. Ülkemizde çocukluk çağıyla ilgili yapılan çalışmalarda DEHB ile akşamcı kronotip arasında anlamlı bir ilişki saptanmamıştı ${ }^{37}$. Çalışmamızda DEHB tanılı olguların kronotip özelliklerine göre dağılımı incelendiğinde; en sık ara tip $(\% 54,5)$, ikinci sıklıkta akşamcı tip (\%33.3), son olarak da sabahçı tip $(\% 12,1)$ saptanmıştır. Poliklinik grubunda yer alan DEHB tanisı almayan olgularda en sık ara tip (\%59.2), ikinci sıklıkta sabahçı tip $(\% 29,9)$, son olarak da akşamcı tip $(\% 10,9)$ saptanmıștır. Sağlıklı kontrol grubunda yer alan olgularda en sık ara tip $(\% 69,7)$, ikinci sıklıkta sabahçı tip $(\% 27,3)$, son olarak da akşamcı tip (\%3) saptanmıştır. Çalışmamızda elde edilen bu sonuçlara göre DEHB'de akşamcllık görülme oranı, genel ve klinik popülasyona göre anlamlı oranda yüksek bulunmuştur. DEHB semptomları ve akşamcılık ilişkisi geçmiş çalışmalarda da incelenmiş ve DEHB patofizyolojisinde gecikmiş melatonin salgısının hem DEHB'deki hiperaktivite bulgularına hem de sirkadiyen döngüde kaymalara neden olduğu öne sürülmüștür ${ }^{38}$. Ülkemizde bu konuda erişkin hasta örnekleminde yapılmış çalışmaya rastlanmamakla birlikte, elde ettiğimiz sonuç literatürde bahsettiğimiz çalışmaların sonuçlarıyla uyumludur. 
DEHB'ye eşlik eden komorbid psikiyatrik bozuklukların araştırıldığı çalışmalarda; çocuklarda \%87, erişkin toplulukta ise \%77’ye varan oranlarda eş tanı varlığı bildirilmektedir ${ }^{39}$. Eş tanı dağılımları yaş gruplarına göre farklılıklar gösterebilmektedir. Erişkinlerde yapılan çalışmalarda en sık rastlanan komorbid psikiyatrik bozuklukların duygudurum bozukluklarl, anksiyete bozuklukları ve alkol ve madde kullanım bozuklukları olduğu bildirilmektedir ${ }^{22}$. $\mathrm{Bu}$ çalışmaların birinde DEHB tanılı erişkinlerin \%88,5'inde en az bir komorbid psikiyatrik bozukluk olduğu saptanmıştır. Bu olgularda en slk görülen komorbid ruhsal bozukluğun depresif bozukluklar olduğu saptanmıştır. Daha sonra sırasıyla anksiyete bozuklukları, alkol ve madde kullanım bozuklukları gelmektedir ${ }^{22}$. Ülkemizde yapılan bir çalışmada DEHB'li olgulara en sık eşlik eden psikiyatrik tanının depresif bozukluklar daha sonra sirasiyla anksiyete bozuklukları (yaygın anksiyete bozukluğu, sosyal fobi, özgül fobi, panik bozukluk) ve obsesif kompulsif bozukluk olduğu saptanmıştır ${ }^{24}$. Çalışmamızda DEHB tanılı olguların \% 81,8'ine komorbid psikiyatrik bozukluğun eşlik ettiği saptanmıştır. Komorbid tanılar içerisinde en sık depresif bozukluklar daha sonra sirasıyla anksiyete bozuklukları, dürtü kontrol bozuklukları ve alkol ve madde kullanım bozuklukları gelmektedir. Çalışmamızda komorbid ruhsal bozukluk eşlik etme oranı literatür ile uyumlu biçimde yüksek bulunmuştur. Depresif bozukluklar $(\% 48,4)$ ve anksiyete bozukluklarının $(\% 30,3)$ görülme sıklığının literatürde yer alan çalışmalara benzer olduğu görülmektedir. $\mathrm{Bu}$ çalışmada saptadığımı Alkol ve madde kullanım bozukluğu oranı (\%9) geçmiş çalışmalara göre daha düşüktür. $\mathrm{Bu}$ durum alkol ve madde kullanan olguların yoksunluk veya uyum sorunları nedeniyle çalışma dışında kalması veya hastanemizde direkt olarak başvuru yapılabilen bir bağımlılık merkezimizin bulunmamasıyla açıklanabilir. Çalışmamızın kısıtlılıkları arasında kronotipin sadece öznel bir özbildirim ölçeği olan SAA ile değerlendirilmiş olması, DEHB tanısı alan hastaların çoğunun eşlik eden ruhsal bozuklukları olması, eşlik eden ruhsal bozuklukların kronotip üzerine karıştırıcı etkileri olması bu nedenle DEHB'ye spesifik özelliklerin net olarak belirnememiş olması sayılabilir. Sadece DEHB belirtileri ile başvuran ve komorbidite saptanmayan hastalar ile yapılacak geniş örneklemli gelecek çalışmalar bu konunun aydınlatılmasında faydalı olacaktır.

Sonuç olarak çalışmamız kronotip alanında yapılmış bir öncü çalışma özelliği taşıyıp araştırmamızın sonuçları literatürde var olan kısıtlı sayıda çalışmadan derlenen bilgiler ile bir arada sunulmuştur. $\mathrm{Bu}$ alanda daha geniş örneklem grubu içeren ve kronotip tercihlerini moleküler düzeyden klinik görünümlerine kadar inceleyecek çalışmalara ihtiyaç duyulmaktadır.

Etik Kurul Kararı: Çalışmanın etik kurul onayı ÇÜTF Girişimsel Olmayan Klinik Araştırmalar Etik Kurulu tarafından verilmiştir (10.11.2017 tarihli toplantı, 11 no'lu karar).

Çıkar Çatışması Beyanı: Yazarlar çıkar çatışması olmadığını bildirmişlerdir.

Finansal Destek: Bu çalışma her hangi bir fon tarafından desteklenmemiştir.

Declaration of Conflicting Interests: The authors declare that they have no conflict of interest.

Financial Disclosure: No financial support was received.

\section{KAYNAKLAR}

1. Tufan AE, Yaluğ İ. Erişkinlerde dikkat eksikliği hiperaktivite bozukluğu: Türkiye verilerine dayalı bir gözden geçirme. Anadolu Psikiyatr Derg. 2010; 11: 351-9.

2. Kessler RC, Adler L, Barkley R, et al. The prevalence and correlates of adult ADHD in the 
United States: results from the National Comorbidity Survey Replication. Am J Psychiatry. 2006; 163: 716-23.

3. Tuğlu C, Şahin ÖÖ. Erişkin dikkat eksikliği hiperaktivite bozukluğu: Nörobiyoloji, tanı sorunları ve klinik özellikler. Psikiyatr güncel yaklaşımlar. 2010; 2: 75-116.

4. Wasserstein J. Diagnostic issues for adolescents and adults with ADHD. J Clin Psychol. 2005; 61: 535-47.

5. Adler LA, Spencer T, Stein MA, Newcorn JH. Best practices in adult ADHD: Epidemiology, impairments and differential diagnosis. CNS Spectr. 2008; 13(Suppl 15): 4.

6. Selvi Y, Beşiroğlu L, Aydın A. Kronobiyoloji ve duygudurum bozuklukları. Psikiyatr Güncel Yaklaşımlar. 2011; 3: 368-86.

7. Adan A, Lachica J, Caci H, Natale V. Circadian typology and temperament and character personality dimensions. Chronobiol Int. 2010; 27: 181-93.

8. Emens JS, Yuhas K, Rough J, Kochar N, Peters D, Lewy AJ. Phase angle of entrainment in morning-and evening-types under naturalistic conditions. Chronobiol Int. 2009; 26: 474-93.

9. Selvi Y, Smolensky MH, Boysan M, et al. Role of patient chronotype on circadian pattern of myocardial infarction: a pilot study. Chronobiol Int. 2011; 28: 371-7.

10. Hasler BP, Allen JJB, Sbarra DA, Bootzin RR, Bernert RA. Morningness-eveningness and depression: Preliminary evidence for the role of the behavioral activation system and positive affect. Psychiatry Res. 2010; 176: 166-73.

11. Doğan S, Öncü B, Varol Saraçoğlu G, Küçükgöncü S. Erişkin dikkat eksikliği hiperaktivite bozukluğu kendi bildirim ölçeği (ASRS-v1. 1): Türkçe formunun geçerlilik ve güvenilirliği. Anadolu Psikiyatr Derg. 2009; 10: 77-87.
12. Turgay IV A. DSM-IV'e Dayalı Erişkin Dikkat Eksikliği Hiperaktivite Bozukluğu Tanı ve Değerlendirme Envanteri, Toronto, İntegratif Ter Enstitüsü, 1995.

13. Horne JA, Östberg O. A self-assessment questionnaire to determine morningnesseveningness in human circadian rhythms. Int J Chronobiol. 1976; 4: 97-110.

14. Corapcioglu A, Aydemir O, Yildiz M, Esen A, Koroglu E. Structured Clinical Interview for DSM-IV (SCID-I) Turkce Formu, Ankara: Hekimler Yayın Birliği, 1999.

15. American Psychiatric Association. Diagnostic and statistical manual of mental disorders (DSM-IV-TR), Washington DC: American Psychiatric Publishing, 2000.

16. American Psychiatric Association. Diagnostic and statistical manual of mental disorders (DSM-5®), Arlington: American Psychiatric Publishing, 2013.

17. Kessler RC, Üstün TB. The world mental health (WMH) survey initiative version of the world health organization (WHO) composite international diagnostic interview (CIDI). Int J Methods Psychiatr Res. 2004; 13: 93-121.

18. Günay Ş, Savran C, Aksoy UM. Erişkin Dikkat Eksikliği Hiperaktivite Ölçeğinin (Adult ADD/ADHD DSM IV-Based Diagnostic Screening and Rating Scale) Dilsel Eşdeğerlilik, geçerlik güvenirlik ve norm çalişmasi. Marmara Üniversitesi Atatürk Eğitim Fakültesi Eğitim Bilim Derg. 2006; 21: 133-50.

19. Pündük Z, Gür H, Ercan İ. Sabahçıl-akşamcıl anketi Türkçe uyarlamasında güvenilirlik çalışması. Türk Psikiyatr Derg. 2005; 16: 40-5.

20. Özkürkçügil A, Aydemir O, Yıldız M, Danacı A, Köroğlu E. DSM-IV Eksen I Bozuklukları için Yapılandırılmış Klinik Görüşmenin Türkçeye Uyarlanması ve Güvenilirlik Çalışması. İlaç ve tedavi Derg. 1999; 12: 233-6. 
21. Fayyad J, De Graaf R, Kessler R, et al. Crossnational prevalence and correlates of adult attention-deficit hyperactivity disorder. $\mathrm{Br} \mathrm{J}$ Psychiatry. 2007; 190: 402-9.

22. Deberdt W, Thome J, Lebrec J, Kraemer S, et al. Prevalence of ADHD in nonpsychotic adult psychiatric care (ADPSYC): a multinational cross-sectional study in Europe. BMC Psychiatry. 2015; 15: 242.

23. Alyanak F, Yargic I, Oflaz S. Genel Psikiyatri Polikliniğinde Erişkin Dikkat EksikliğiHiperaktivite Bozukluğu Sıklığı ve Dikkat Eksikliği-Hiperaktivite Bozukluğuna Eşlik Eden Diğer Psikiyatrik Bozukluklar. Nöro Psikiyatr Arşivi. 2011; 48: 119-24.

24. Duran S, Fistikci N, Keyvan A, Bilici M, Çaliskan M. Ayaktan psikiyatri hastalarinda dikkat eksikligi ve hiperaktivite bozuklugu: yayginlik ve estanilar. Turk Psikiyatr Derg. 2014; 84-93.

25. Willcutt EG. The prevalence of DSM-IV attention-deficit/hyperactivity disorder: a meta-analytic review. Neurotherapeutics. 2012; 9: 490-9.

26. Polanczyk G, Rohde LA. Epidemiology of attention-deficit/hyperactivity disorder across the lifespan. Curr Opin Psychiatry. 2007; 20: 386-92.

27. Williamson D, Johnston C. Gender differences in adults with attentiondeficit/hyperactivity disorder: A narrative review. Clin Psychol Rev. 2015; 40: 15-27.

28. Öncü B, Şenol S. Dikkat eksikliği hiperaktivite bozukluğunun etiyolojisi: Bütüncül yaklaşım. Klin Psikiyatr Derg. 2002; 5: 111-9.

29. Tamam L, Demirkol ME. Erişkin dikkat eksikliği/hiperaktivite bozukluğu ve duygudurum bozuklukları. Turkiye Klin J Psychiatry Spec Top. 2012; 5: 48-53.
30. Ozdemir N, Erginyavuz KA. Being a mother of children with ADHD and the problems it causes to mothers. New Trends Issues Proc Humanit Soc Sci. 2019; 6: 425-9.

31. Park S, Cho MJ, Chang SM, et al. Prevalence, correlates, and comorbidities of adult ADHD symptoms in Korea: results of the Korean epidemiologic catchment area study. Psychiatry Res. 2011; 186: 378-83.

32. Barkley RA, Murphy KR, Kwasnik D. Motor vehicle driving competencies and risks in teens and young adults with attention deficit hyperactivity disorder. Pediatrics. 1996; 98 : 1089-95.

33. Baird AL, Coogan AN, Siddiqui A, Donev RM, Thome J. Adult attention-deficit hyperactivity disorder is associated with alterations in circadian rhythms at the behavioural, endocrine and molecular levels. Mol Psychiatry. 2012; 17 : 988-95.

34. Bae S, Park JE, Lee YJ, et al. Gender difference in the association between adult attention deficit hyperactivity disorder symptoms and morningness-eveningness. Psychiatry Clin Neurosci. 2010; 64: 649-51.

35. Rybak YE, McNeely HE, Mackenzie BE, Jain UR, Levitan RD. Seasonality and circadian preference in adult attentiondeficit/hyperactivity disorder: clinical and neuropsychological correlates. Compr Psychiatry. 2007; 48: 562-71.

36. Bumb JM, Mier D, Noelte I, et al. Associations of pineal volume, chronotype and symptom severity in adults with attention deficit hyperactivity disorder and healthy controls. Eur Neuropsychopharmacol. 2016; 26: 1119-26.

37. Tarakçioğlu MC, Kadak MT, Gürbüz GA, et al. Evaluation of the relationship between attention deficit hyperactivity disorder symptoms and chronotype. Arch Neuropsychiatry. 2018; 55: 54. 
38. Bijlenga $\mathrm{D}$, van der Heijden $\mathrm{KB}$, Breuk $\mathrm{M}$, et al. Associations between sleep characteristics, seasonal depressive symptoms, lifestyle, and ADHD symptoms in adults. J Atten Disord. 2013; 17: 261-75.
39. Sobanski E, Brüggemann D, Alm B, et al. Psychiatric comorbidity and functional impairment in a clinically referred sample of adults with attention-deficit/hyperactivity disorder (ADHD). Eur Arch Psychiatry Clin Neurosci. 2007; 257: 371-7. 